\title{
MOLECULAR BIOLOGY IN YOUNG WOMEN WITH BREAST CANCER: FROM TUMOR GENE EXPRESSION TO DNA MUTATIONS
}

\author{
Liliana Gómez-Flores-Ramos ${ }^{1,2,3 *}$, Andrea Castro-SánChez ${ }^{4,5}$, Omar Peña-Curiel ${ }^{6}$ AND \\ AlejANDRO MOHAR-BETANCOURT ${ }^{1,2,3}$
}

${ }^{1}$ Instituto de Investigaciones Biomédicas; ${ }^{2}$ Unidad de Investigación Biomédica en Cáncer, Universidad Nacional Autónoma de México; ${ }^{3}$ Unidad de Epidemiología, Instituto Nacional de Cancerología; “"Joven y Fuerte: Programa para la Atención e Investigación de Mujeres Jóvenes con Cáncer de Mama en México"; ${ }^{5}$ Cátedras CONACYT, Instituto Nacional de Cancerología; ${ }^{6}$ Centro de Cáncer de Mama, Tecnológico de Monterrey, Mexico City, Mexico

\begin{abstract}
Young women with breast cancer (YWBC) represent roughly $15 \%$ of breast cancer (BC) cases in Latin America and other developing regions. Breast tumors occurring at an early age are more aggressive and have an overall worse prognosis compared to breast tumors in postmenopausal women. The expression of relevant proliferation biomarkers such as endocrine receptors and human epidermal growth factor receptor 2 appears to be unique in YWBC. Moreover, histopathological, molecular, genetic, and genomic studies have shown that YWBC exhibit a higher frequency of aggressive subtypes, differential tumor gene expression, increased genetic susceptibility, and specific genomic signatures, compared to older women with BC. This article reviews the current knowledge on tumor biology and genomic signatures in YWBC.
\end{abstract}

Key words: Breast cancer. Young women. Molecular biology. Hereditary breast cancer.

\section{INTRODUCTION}

Breast cancer (BC) is the most common malignancy in women worldwide, representing about $25 \%$ of the cancer cases, and is the leading cause of cancer-related deaths in most countries ${ }^{1}$. In developed regions, such as the European Union and North America, the occurrence of malignant breast tumors predominates during the fifth decade of life ${ }^{1}$. However, $5-8 \%$ of cases occur in women younger than 45 years of age ${ }^{2}$. In contrast, the reported incidence rates of young women with $B C$ (YWBC) in developing countries are as high as $10-15 \%$ and also show a higher mortality rate r.5 $^{2-5}$

Corresponding author:

*Liliana Gómez-Flores-Ramos

Unidad de Investigación en Epidemiología

Instituto Nacional de Cancerología

Av. San Fernando, 22

Col. Sección XVI, Del. Tlalpan

C.P. 14080, Mexico City, Mexico

E-mail: dralilianag@gmail.com
The age definition of YWBC varies in the literature, referring to women under the ages of 35,40 , or 45 as "young". However, there seems to be a biological and clinically meaningful difference among premenopausal women with $B C$ onset by age $<40$ years, suggesting this age as a relevant cut-point ${ }^{6}$. Further, YWBC represents a challenge for public health due to its high mortality rate, loss of potential quality-adjusted life years, delayed diagnosis, treatment complexity, and costs. These reasons have opened the field of new basic and clinical research on the tumor biology of $\mathrm{YWBC}^{7-10}$. This review focuses on the current knowledge of the histopathological features, the genomic signatures, and molecular biology of the tumors in YWBC.

Received for publication: 31-03-2017

Accepted for publication: 20-06-2017

doi: 10.24875/RIC.17002225 


\section{HISTOPATHOLOGIC FEATURES OF TUMORS IN YOUNG WOMEN}

Young age is considered an independent negative prognostic factor for local recurrence ${ }^{11-13}$, contralateral $\mathrm{BC}^{14,15}$, and overall outcomes ${ }^{16,17}$. In addition, YWBC patients report a higher incidence of a family history of cancer, particularly $\mathrm{BC}^{18,19}$, suggesting a genetic component involved in the etiology of early-onset $\mathrm{BC}^{19,20}$.

Breast tumors in young women have been described as being more aggressive than in their older counterparts ${ }^{6,21}$. This aggressiveness may be in part explained by the more frequent finding of a higher histological tumor grade and proliferation index. Tumors from young women express higher levels of the cellular proliferation associated antigen Ki6722,23. Furthermore, the other well-known prognostic biomarkers, including estrogen receptor (ER) and progesterone receptors (PR) and human epidermal growth factor receptor 2 (HER2), differ in young women compared to older women ${ }^{6,10,23-26 .}$.

In the Prospective Study of Outcomes in Sporadic and Hereditary Breast Cancer study, Copson et al. described the histopathological features of a cohort of 2956 patients < 40 years with BC. They reported a median age at diagnosis of 36 years, median tumor size of $22 \mathrm{~mm}$, and up to $50 \%$ of patients had axillary lymph node metastases at diagnosis. Moreover, $59 \%$ of the tumors were high grade, $34 \%$ ER-negative (ER-), and 24\% HER2-positive (HER2+). Patients with ER- tumors were associated with a worse 5-year overall survival (OS) compared with ER-positive (ER+) tumors ${ }^{27}$.

Regarding the molecular phenotype according to ER, PR, HER2 and Ki67 expression, Collins et al. ${ }^{26}$ analyzed the different subtypes of BC among 399 women aged $\leq 40$ years. They found a $35 \%$ rate of luminal $B$ tumors, defined as ER+, PR+, and HER2+ or both ER+ and PR+, HER2 - and Grade 3, whereas the rate of luminal $A$ tumors, defined as $E R+$ and PR+, HER 2 - and Grade 1 or 2, was only $33 \%$. HER2 enriched tumors accounted for $11 \%$ of the patients, and triple negative phenotype was found in $21 \%$ of the cohort. In Hispanic population, Villarreal-Garza et al. ${ }^{16}$ found a similar distribution of BC subtypes and confirmed the worst 5 -year OS for young women with luminal B subtype compared to older patients
( $79 \%$ vs. $85 \%)^{16}$. Fig. 1 describes the BC subtypes according to age, determined by gene expression profiling.

\section{MOLECULAR FEATURES OF TUMORS IN YOUNG WOMEN}

\section{Tumor gene expression profiling}

During the last decade, significant efforts to describe the molecular biology of early-onset BC have been made. Anders et al. ${ }^{20,28}$ evaluated somatic gene expression profiling in breast tumor tissue in a cohort of 200 young women ( $\leq 45$ years) and an older age cohort of 211 patients ( $\geq 65$ years). Using genomic mRNA expression analysis, they showed that tumors in young women had significantly lower mRNA expression of ER $\alpha, E R \beta$, and PR, and higher HER2 and epidermal growth factor receptor (EGFR) expression. Further, in multivariate analysis of the young women's cohort, lower mRNA expression of ER and higher expression of EGFR predicted inferior disease-free survival. Moreover, exploratory gene set enrichment analysis revealed 367 genes differentially expressed between tumors from young women and their older counterparts. These included genes involved in immune regulation, mammalian target of rapamycin/rapamycin signaling, hypoxia-regulating genes, BRCA1, stem cells, apoptosis, histone deacetylase, and growth and differentiation pathways such as Myc, E2F, Ras, $\beta$-catenin, AKT, P53,

Figure 1. Breast cancer subtypes according to age, determined by gene expression profiling.

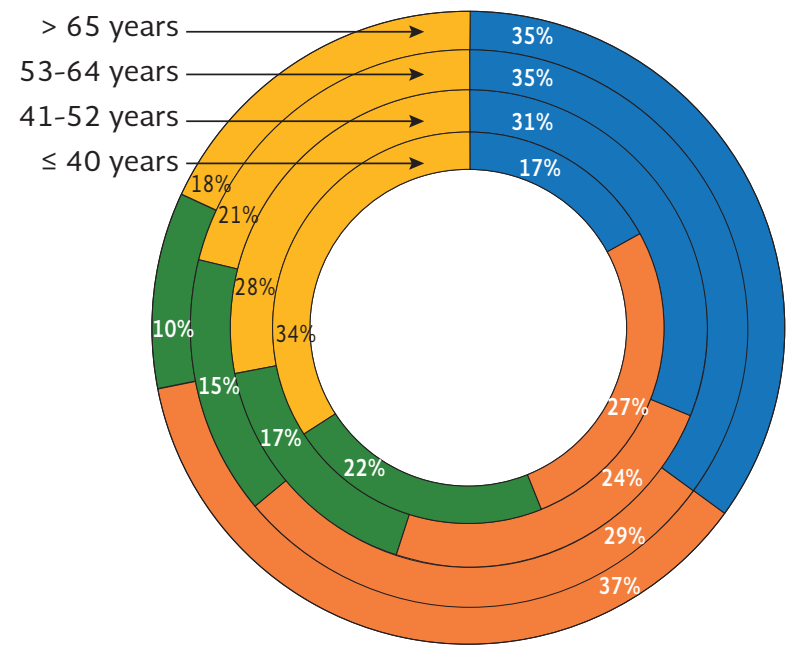

Luminal-A $\square$ Luminal-B $\square$ HER2 $\square$ Basal 
phosphatase and tensin homolog (PTEN), and mitogen-activated protein kinase (MAPK), with potential prognostic and therapeutic significance in $\mathrm{YWBC}^{20}$. These results showed, for the first time, that breast tumors in young women share a particular gene expression pattern which may influence its characteristic biologic behavior ${ }^{28}$.

Azim et al. ${ }^{29}$ conducted a pooled gene expression analysis on two datasets including 1188 and 2334 patients with nearly 50 genes that were related to early-onset $B C$. The analysis was adjusted for differences in BC molecular subtype, histological grade, tumor size, and nodal status. Results on the first dataset ( $\leq 40$ years, $n=191$ ) showed that independent of subtype, grade and stage, younger patients have a higher expression of RANK-ligand and c-kit, in addition to mammary stem cell luminal progenitors and BRCA1 mutation signatures. Furthermore, there was more disruption of MAPK and phosphoinositide 3-kinase ( $P I 3 K$ ) pathways and lower expression of BRCA1 and several apoptosis-related genes, particularly FAS. The same findings were reproduced in an independent dataset that included 260 patients who were aged $\leq 40$ years ${ }^{30}$.

Colak et al. ${ }^{31}$ analyzed the expression signatures of breast tumors in Middle-Eastern YWBC using genomewide gene expression assays. They compared the transcriptome from $\mathrm{BC}$ tumors in three different age cohorts from young women ( $<45$ years), pre-elderly women (45-55 years) and elderly patients ( $>55$ years). They identified 63 genes with distinct expression patterns in young women, including those associated with PI3K/ Akt, MYC, nuclear factor kappa B, transforming growth factor-alpha, ErbB2, and interleukin (IL1)/IL1R signaling pathways, which may promote angiogenesis, tumor growth, and metastasis, leading to the aggressive phenotype observed in young women.

\section{Somatic gene expression profiling during pregnancy and lactation}

Pregnancy-associated $B C$ is a particular issue in $Y W B C$. The female breast is a tissue that changes during different biological stages; in young women, the constant fluctuations of steroid hormones over a lifetime affect mammary tissue, which contains a high amount of enriched immature mammary cell populations (stem cells and progenitors), that increase during pregnancy and breastfeeding ${ }^{32}$. Collectively, these events might raise the risk of $\mathrm{BC}$ transformation through genome instability, increasing the probability of random genetic mutations and reducing immune surveillance $^{32}$. Reproductive history impacts the prognosis of YWBC; in this regard, patients diagnosed within the next 5 years postpartum have a worse prognosis than nulliparous women or than those diagnosed during pregnancy $^{33}$.

Azim et al. ${ }^{34}$ compared two groups of YWBC, pregnant and nonpregnant. Among the pregnant group, tumors had a higher expression of PD1, PD-L1, and 54 genes related to $S R C$, insulin-like growth factor, and $\beta$-catenin. The expression of these genes appeared to increase during gestation in the normal breast tissue, emphasizing on the potential effects of the breast microenvironment on tumor phenotype ${ }^{34}$.

There is a temporary increase in BC risk within the following 5 years postpartum due to mammary gland involution, which is considered a risk factor for tumorigenesis and tumor progression ${ }^{35,36}$. In a murine model, Lyons et al. ${ }^{33}$ found that mammary gland involution is a driving force for tumor progression. In this model, human BC cells were injected to involuting mouse mammary glands; the authors observed the progression from ductal in situ carcinoma to invasive ductal carcinoma, forming large tumors with abundant fibrillar collagen content, high cyclooxygenase-2 expression (COX-2), and an invasive tumor microenvironment. Furthermore, they found that pharmacological inhibition of COX-2 reduced the collagen fibrinogenesis, tumor growth, and cell infiltration to the lung ${ }^{33}$.

These experimental studies suggest that changes occurring during the peripartum period may impact on the biology of BC development in young women. These changes are probably induced by hormonal and inflammatory factors and the resulting adjustment of the breast microenvironment. However, data are still insufficient to conclude that such effects play a fundamental role in carcinogenesis and tumor biology ${ }^{34}$.

\section{Micro-RNA (mi-RNA) expression profiles in YWBC}

miRNAs are short non-coding RNA sequences that regulate gene expression by complementary binding to target mRNA transcripts, usually resulting in transcriptional repression or target degradation ${ }^{37}$. Functional studies have confirmed that miRNA 
dysregulation is involved in the initiation, progression, and metastasis of human cancers, including BC, making miRNAs a potential therapeutic target ${ }^{38,39}$. Some experimental data suggest that there is a particular miRNA expression pattern in $\mathrm{YWBC}^{40-42}$.

Peña-Chilet et al. ${ }^{40}$ studied the miRNA profile of 45 YWBC (defined as $\leq 35$ years) compared to older women and found a unique expression of 96 miRNAs according to age $(p<0.05)$. The research group validated the expression of 6 miRNAs, finding upregulation of miRNA-1228*, miRNA-3196, miRNA-1275, and miRNA-1207, and downregulation of miRNA-139-5p and miRNA-92b. These miRNAs are involved in pathways related to cell motility and apoptosis, mitotic and proliferation regulatory mechanisms, and the PI3K and IGFR signaling, all these features associated with higher metastatic capacity ${ }^{40}$.

$\mathrm{Li}$ et $\mathrm{al} .{ }^{41}$ analyzed the expression of miRNA-146a and miRNA-146b in 120 YWBC and 130 patients with breast fibroadenomas. The levels of miRNAs were lower in $\mathrm{BC}$ compared to fibroadenomas and precancerous breast tissue $(p<0.005)$. In breast tumor tissue, the downregulation of miRNA-14a/b was associated with ER/PR-, HER2-, Ki-67 index $\geq 20 \%$, tumor size $>2 \mathrm{~cm}$, distant metastasis, lymph node metastasis, advanced clinical tumor, node and metastasis stages (III-IV), and basal-like phenotype ${ }^{41}$. In BC, these miRNAs are associated with down-regulation of BRCA1 through binding to the $3^{\prime} U T R$ of this gene ${ }^{43}$. These results suggest that miRNA-146a/b could be a potential biomarker for YWBC.

Nassar et al. ${ }^{42}$ studied the miRNA expression in 57 breast tumor samples from young women. They found a significant upregulation of miRNA-155, miRNA-21, and miRNA-148b along with downregulation of miRNA-10b, which positively correlated with ER and PR expression. Moreover, miRNA-155 was overexpressed in women diagnosed after the age of 40 , suggesting that it could be a potential biomarker for age at diagnosis ${ }^{42}$. The expression of miRNA-21 has been reported to contribute to invasion and metastasis by targeting tumor suppressors PTEN, PDCD4, mammary serine protease inhibitor (Maspin), and a number of other genes involved in tumor proliferation and metastasis ${ }^{44,45}$. The expression of miRNA-148b has been associated with $B C$ progression in a relapse-associated miRNA signature by targeting ITGA5, ROCK1, PIK3CA, NRAS, and CSF1 ${ }^{46}$. The miRNA-10b inhibits translation of mRNA encoding homeobox D10, which leads to increased expression of the pro-metastatic gene $\mathrm{RHOC}^{47}$.

Recently, miRNAs have risen as potential biomarkers and key molecular regulators of the pathogenesis and progression of BC. miRNAs can be detected in blood, increasing their potential as noninvasive biomarkers. Furthermore, there is a growing body of evidence of miRNAs' association with drug resistance, again suggesting a role as therapeutic targets ${ }^{48}$. Although research has clarified the role of miRNAs in BC, it is important to standardize the experimental protocols to validate these results before translation to the clinical arena ${ }^{49}$.

\section{Epigenetic profile in YWBC}

The differentiation and diversity of cellular functions are regulated by many factors, including the methylation-regulated pattern of gene expression. Aberrant methylation patterns in tumor cells are associated with the development of $\mathrm{BC}^{50,51}$. Wong et al. ${ }^{52}$ demonstrated that the constitutional DNA methylation of the $B R C A 1$ promoter was significantly associated with an increased risk of early-onset $B C$ in women under the age of 40 years. The clinical features of women with constitutionally silenced $B R C A 1$ were similar to the characteristics of patients with germline mutated $B R C A 1$, indicating that methylation patterns can mimic germline mutations ${ }^{52}$.

Scott et al. ${ }^{51}$ examined the role of methylation in a broad set of high and moderate $B C$ susceptibility genes in 43 women diagnosed with $B C$ before the age of 40 years negative for germline mutations in the genes included in the study. The methylation patterns across the promoter regions of BRCA1, BRCA2, Ataxia Telangiectasia Mutated (ATM), partner and localizer of BRCA2 (PALB2), CDH1, TP53, FANCM, checkpoint serine threonine kinase 2 (CHEK2), MLH1, MSH2, MSH6, and PMS2 were analyzed in blood and tumor DNA samples. There were significant differences between blood and tumor DNA methylation patterns. In tumors, there was an increased methylation of $B R C A 1, B R C A 2$, ATM, CHEK2, MLH1, MSH2, and MSH6, while methylation in $C D H 1$ was increased in the blood. PMS2 was hypomethylated, and PALB2 was hypermethylated in most of the tumor samples ${ }^{40,43,53}$. This study yielded interesting insights on specific methylation patterns in the main genes involved in $\mathrm{BC}$ carcinogenesis. Further 
research is necessary to confirm these findings in larger groups of young patients with BC.

Interesting, almost $25 \%$ of the patients included in the studies discussed above ${ }^{52,53}$ presented increased constitutive methylation of the BRCA1 promoter and showed similar phenotypes of germinal mutations in $B R C A 1$. Hence, $B R C A 1$ promoter methylation may be an interesting biomarker given its clear clinicopathological correlation, and the fact that it can be detected in circulation.

\section{SOMATIC MUTATION PROFILE IN YWBC}

Somatic mutations have been found in all types of human cancer. In $\mathrm{BC}$, the most frequently mutated genes are PIK3CA (25\%), TP53 (23\%), CDH1 (11\%), GATA3 (7\%), and PTEN (5\%) 54,55 . In YWBC, Encinas et al. ${ }^{56}$ performed a systematic review to analyze whether somatic mutations in five genes were associated with an early age at presentation of $B C$. They found a higher frequency of wild-type PIK3CA associated with early-onset $B C$, although not statistically significant when employing a multivariate model. Moreover, TP53 was mutated in $20 \%$ of tumors from both younger and older patients ${ }^{56}$. Azim et al. ${ }^{29}$ examined the genomic aberrations of tumors from three different age groups, $\leq 45$ (125 patients), 46-69 (486 patients), and $\geq 70$ (169 patients) years of age. There was a strong positive correlation between age and somatic mutations and copy number variations (CNVs), particularly in ductal tumors. Although eleven mutations were independently associated with age at diagnosis, only mutations in GATA3 were related to young age and were twice as frequent in young patients (Fig. 2). Only one $\mathrm{CNV}$ event was linked to early-onset $\mathrm{BC}$, with deletions in locus $6 q 27^{29}$.
At present, GATA3 mutations are the main characteristic somatic aberrations detected in YWBC. GATA3 directly upregulates proto-oncogenes and ER $\alpha$ suggesting that it may promote tumorigenesis in luminal subtypes of cancer $^{57}$. Mutations in GATA3 affect ER binding to $D N A^{58}$ and modulate the response of tumor cells to estrogen signaling, which might be associated with endocrine resistance and tumor growth ${ }^{59,60}$. These results may take clinical relevance since the adverse prognosis associated with younger age at diagnosis has been observed mainly in patients with $\mathrm{ER}+\mathrm{BC}^{16}$.

\section{GERMLINE GENOMIC PROFILE IN YWBC}

\section{$\mathrm{BC}$-predisposing gene mutations}

In cancer, early age of presentation suggests a high genetic susceptibility to the disease. In women with BC, about 1 in 10 cases represents a form of hereditary BC (Fig. 3) ${ }^{61,62}$; however, in young patients, this genetic susceptibility may be higher. Predisposing gene mutations can be classified according to the relative risk (RR) of developing cancer when a patient carries a particular germline mutation. Highly penetrant mutations are associated with a cancer RR $>5.0$, moderate penetrant mutations RR ranges from 1.5 to 5.0 , and low-penetrant loci changes are associated with an estimated RR of 1.5 (usually polymorphisms) ${ }^{63}$.

\section{Highly penetrant genes}

Mutations in highly penetrant genes are responsible for the most common autosomal dominant hereditary cancer syndromes; these genes are involved in critical steps of DNA repair, apoptosis and cell proliferation (Table 1 and Fig. 4).

Figure 2. Frequent somatic mutations in women with breast cancer according to age.
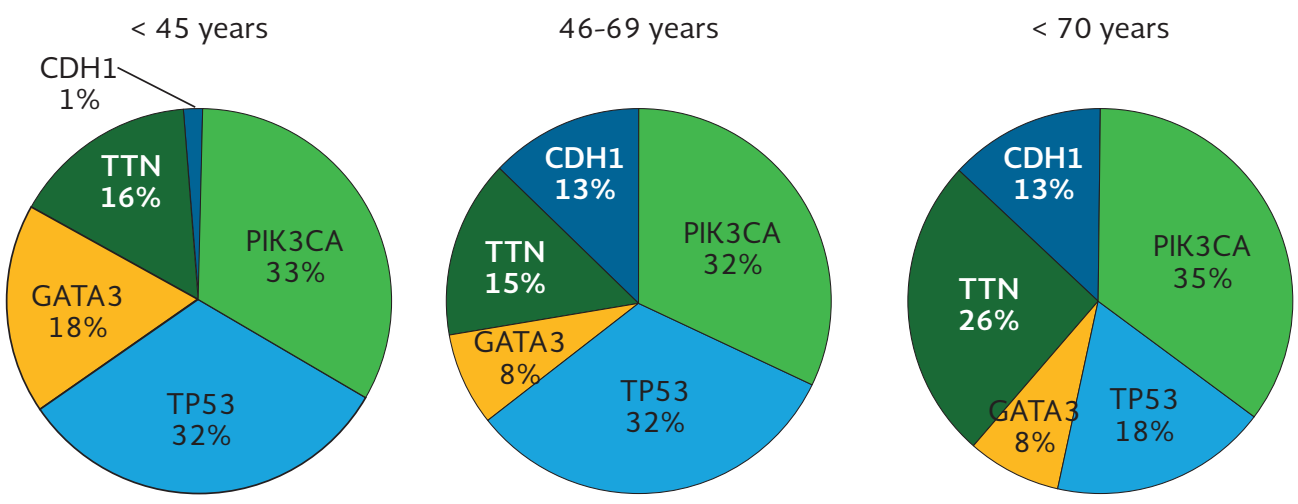
Table 1. Genetic mutations in YWBC.

\begin{tabular}{|c|c|c|c|}
\hline Risk Loci & High-penetrance & Moderate-penetrance & Low-penetrance \\
\hline Gens & $\begin{array}{l}\text { BRCA1/2, PT53, PTEN, } \\
\text { STK11, CDH1 }\end{array}$ & $\begin{array}{l}\text { CHEK2, PALB2, ATM, BRIP1, } \\
\text { BARD1, MRN complex, RAD51 } \\
\text { and paralogs }\end{array}$ & $\begin{array}{l}\text { 10q26.13 (FGFR2), 2q33 (CASP8), } \\
\text { 5q11.2; (MAP3K1), 11P15.5 (LSP1), } \\
\text { 16q12.1 (TNRC9), 6q25 (ESR1), } \\
14 q 24 \text { (RAD51L1), 2q35, 8q24, 5p12, 1p11 }\end{array}$ \\
\hline Cancer risk (RR) & $>5$ & $1.5-5$ & $1.1-1.5$ \\
\hline Functional effect & Direct effect of mutation & Direct effect of candidate gene & Linkage disequilibrium with causal variants \\
\hline $\begin{array}{l}\text { Population } \\
\text { frequency }\end{array}$ & $<0.1 \%$ & $<1 \%$ & $>10 \%$ \\
\hline $\begin{array}{l}\text { Strategy for } \\
\text { identification }\end{array}$ & $\begin{array}{l}\text { Linkage and positional } \\
\text { cloning; resequencing of } \\
\text { candidate genes }\end{array}$ & Resequencing of candidate genes & $\begin{array}{l}\text { Case-control studies; genome-wide } \\
\text { association study }\end{array}$ \\
\hline
\end{tabular}

YWBC: young women with breast cancer; ATM: ataxia Telangiectasia Mutated; BARD1: BRCA1 associated RING domain 1; FGFR2: fibroblast growth factor receptor 2

Figure 3. Genetic susceptibility to breast cancer.

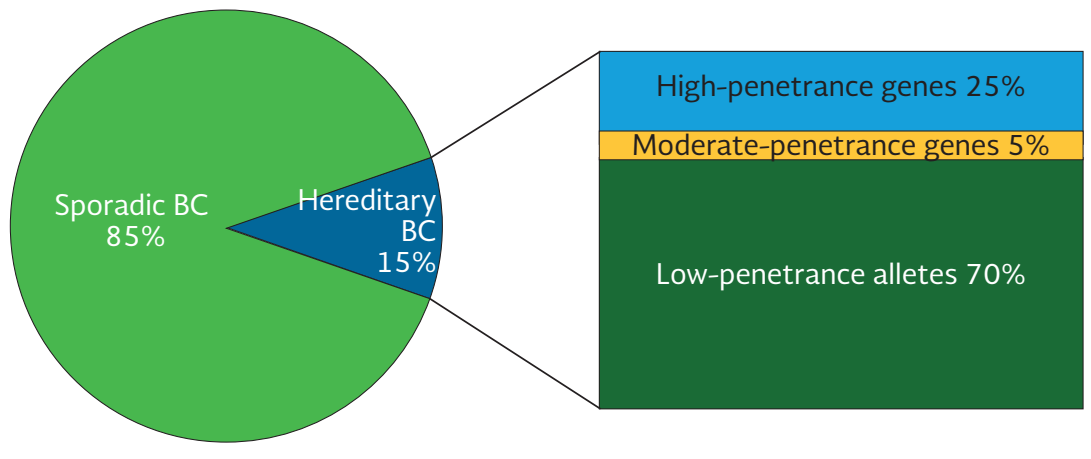

Figure 4. Relative frequency of mutations in cancer associated genes detected by next generation sequencing in young women with breast cancer.

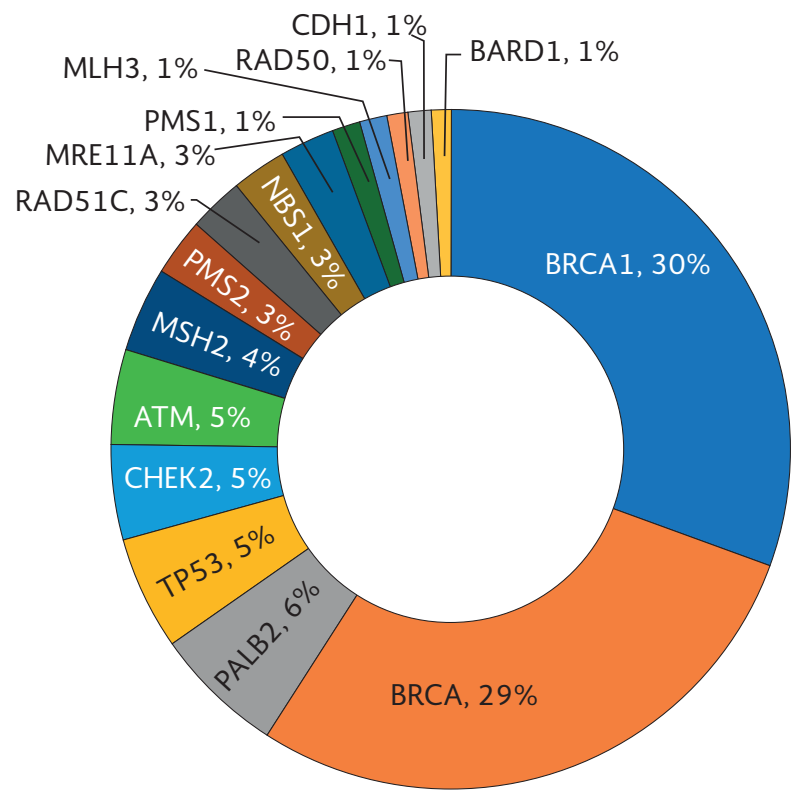

\section{BRCA1/2}

Mutations leading to the premature termination of the BRCA1/2 proteins are responsible for the Hereditary Breast and Ovarian Cancer syndrome. The lifetime risks of $B C$ can be as high as $80 \%$ in women carrying a BRCA1 mutation ${ }^{64}$. The chance of carrying a germline mutation in $B R C A 1 / 2$ in very $Y W B C$ is almost $10 \%$ for patients without a family history of $\mathrm{BC}$ and $12 \%$ for patients with a family history of $\mathrm{BC}^{65}$. In young patients with negative ER subtype $\mathrm{BC}$ and high-grade tumors, the probability of having a BRCA1 mutation is close to $30 \% 66,67$. Significant research has been made to describe the recurrent mutations in Mexican women with BC, and more than 100 deleterious variants have been found to occur among our population ${ }^{66}$. In unselected women with BC, Torres-Mejía et al. described 20 mutations in $B R C A 1$ and 15 in BRCA2. Of these mutations, $63 \%$ were recurrent, including the deletion of exons 9-12 
in BRCA1 (ex9-12del), considered a founder mutation in the Mexican population, which accounted for almost $25 \%$ of all the mutations in $B R C A 1^{68}$. Villarreal-Garza et al. described BRCA1/2 mutations among Mexican YWBC with triple-negative BC. 23\% of the 190 patients tested carried a BRCA mutation; 43 mutations accounted for $89 \%$ of the total mutations, and BRCA1 ex $9-12 \mathrm{del}$ accounted for $41 \%$ of all the mutations detected ${ }^{66}$.

\section{TP53}

Mutations in TP53 gene are highly penetrant and associated with a variety of human cancers in the spectrum of the Li-Fraumeni syndrome ${ }^{67}$. The lifetime risk of BC for carriers of mutations in TP53 is up to $50 \%{ }^{69}$. The reported frequency of TP53 mutations in women diagnosed before 35 years of age ranges from $<1 \%$ to $7 \%{ }^{69-73}$ and up to $30 \%$ for patients diagnosed before the age of 30 years.

\section{PTEN}

Germline mutations in PTEN lead to the clinical manifestations collectively labeled as PTEN hamartoma tumor syndrome ${ }^{74}$. Women with mutations in PTEN have a $B C$ risk in the range of $70-85 \% 75,76$, and in YWBC, the reported frequency of mutations in this gene represents $<1 \%{ }^{77}$.

\section{STK11}

The cumulative incidence of $\mathrm{BC}$ in patients with mutations in STK11 is approximately $45 \%^{78,79}$. Tumors usually appear at a mean age of 41.5 years, with a higher risk in females than in males (22-fold increase) and a $20 \%$ risk of any cancer by the age of 40 compared to the general population ${ }^{80-82}$. In women with germline STK11 gene mutations, the risk of BC by age 40 is $31 \%^{83}$.

\section{$\mathrm{CDH1}$}

Germline mutations in $\mathrm{CDH} 1$ have been associated with hereditary diffuse gastric carcinoma ${ }^{84}$. Carriers of $\mathrm{CDH} 1$ mutations face a $40-54 \%$ lifetime risk of developing $\mathrm{BC}^{85}$. Without a family history of hereditary diffuse gastric carcinoma, early-onset, and frequently bilateral BC, seems to be the highest risk factors for a mutation carrier ${ }^{86-89}$.

\section{Moderate-penetrance genes}

Moderate-penetrance genes code for proteins that participate in complexes of DNA repair, cell cycle, and apoptosis, recruiting or interacting with polypeptides coded by highly penetrant genes. These genes include CHEK2, PALB2, ATM, and BRCA1 interacting protein c-terminal helicase 1 (BRIP1), among others (Table 1 and Fig. 4).

\section{CHEK2}

Mutations in CHEK2 increase BC risk from 3- to 5 -fold ${ }^{90,91}$. The most studied germline mutation, c.1100delC, significantly augments the risk of early-onset and familial $B C^{91}$. Other mutations have been reported in very young Pakistani women (p.P92R, p.R406C, p.H371Y, and p.D438Y) $)^{92,93}$, and in Chinese very young women $(1169 \mathrm{~A}>\mathrm{G})^{94}$.

\section{PALB2}

Mutations in the PALB2 increase the risk of $B C$ in 9- to 10 -fold in women younger than 40 compared to the general population ${ }^{95}$. According to different ethnic reports ${ }^{95-100}$, about $1 \%$ of women with early-onset BCs negative for BRCA1/2 mutations carry a mutation in this gene.

\section{ATM}

Women younger than 50 years who are heterozygote carriers of deleterious variants of the ATM gene have a 5 -fold higher risk for $\mathrm{BC}^{101}$. Mutations in the ATM gene have been described in YWBC and are considerably more frequent when there is a familial history ${ }^{102-107}$.

\section{BRIP1}

Mutations in the BRIP1 gene seem to be more frequent in women with early-onset $B C$ and triple-negative $B C^{108}$. About $1 \%$ of patients with early-onset or familial BC carry a deleterious mutation ${ }^{103}$.

\section{BRCA1 associated RING domain 1 (BARD1)}

The most described mutation in BARD1 gene is Cys557Ser; this variant is commonly found in women younger than 50 years from Nordic population ${ }^{109,110}$. In Finnish families with breast and ovarian cancer, the variant $557 \mathrm{Ser}$ has a frequency of $7.4 \%{ }^{109}$. In an 
Icelandic population, the mutant allele 557 Ser had a $3.7 \%$ frequency in cases with a family history of $B C$, early-onset $\mathrm{BC}$, or multiple primary $\mathrm{BC} \mathrm{s}^{110}$.

\section{MRN complex}

The MRN complex is composed of dimers of the three proteins encoded by the MRE11A, RAD50, and NBN genes $^{111}$. Deleterious mutations have been identified in all three genes of the MRN complex. The study done by Damiola et al., which included 1313 women $<45$ years old with $B C$, found that rare MRN gene variants significantly contribute to early-onset $B C$ susceptibility ${ }^{112}$. NBN has the strongest evidence of acting as a BC risk gene ${ }^{113,114}$. The risk of developing any malignancy by the age of 20 in patients with NBS is $>40 \%{ }^{115}$.

\section{RAD51 and paralogs}

The RAD51 family comprises five paralogous proteins, RAD51B, RAD51C, RAD51D, XRCC2 and XRCC3, which transduce the DNA damage signal to promote break repair ${ }^{116}$ and interacts with $\mathrm{p} 53^{117}, \mathrm{BRCA} 1^{118}$, BRCA2 $2^{119}$ and PALB2 ${ }^{120}$ pathways. The results of a study in French patients with early-onset or familial breast and/or ovarian cancers negative for BRCA1/2 mutations found two probable deleterious missense variants: RAD51B c. $452+3 \mathrm{~A}>\mathrm{G}$ and RAD51C c.706-2A > G ( $<45$ years old), and three splicing mutations: RAD51C c.1026+5_1026+7del, RAD51B c. $475 \mathrm{C}>\mathrm{T} / \mathrm{p}$.Arg 159 Cys ( $<50$ years old), and XRCC3 c. $448 \mathrm{C}>\mathrm{T} / \mathrm{p} . \operatorname{Arg} 150 \mathrm{Cys}^{121}$.

\section{Low-penetrance BC LOCI}

The polygenic model has emerged as an efficient tool to allow the detection and assessment of small risk loci when highly- and moderately-penetrant mutations cannot explain the phenotype (Table 1) 122-125. Low-penetrance loci are more commonly found in genome-wide association studies (GWAS).

\section{GWAS}

GWAS analyze considerable amounts of genomic data on large population groups; most of GWAS conducted in BC patients are focused in postmenopausal women of Caucasian ancestry, making it difficult to assess an overall risk for a particular genetic variant, and leaving other age and ethnic groups underrepresented ${ }^{122,125}$.
There are two GWAS that the present data of early-onset $\mathrm{BC}^{122,123}$. The study by Ahsan et al., which included 3523 early-onset BC cases, detected 12 independently associated single nucleotide polymorphisms (SNPs); 11 of these SNPs were in the 5q11.2 locus, within or near the MAP3K1 gene. The other locus was the phosphofructokinase muscle (PFKM) gene on chromosome 12q13.11. This study also found 32 additional risk loci shared between early- and late-onset $\mathrm{BC}^{123}$. The second GWAS, which included Caucasian and African-American women with BC, detected a significant association between the GTGT haplotype (rs11200014, rs2981579, rs1219648 and rs2420946) in fibroblast growth factor receptor 2 and the risk of early onset $\mathrm{BC}^{124}$.

\section{Predictive and prognostic genetic variants}

The expression of the BRCA1/BRCA2/Rad51 complex is essential in the homologous recombination repair pathways; this complex has proved to be a useful prognostic biomarker in early onset BC. In the study conducted by Söderlund et al., the patients with low expression of the BRCA1/BRCA2/Rad51 complex had more local recurrences, high histologic grade, and good response to radiotherapy compared to patients with high expression of the complex ${ }^{126}$. The polymorphism $135 \mathrm{G}>\mathrm{C}$ in the RAD51 gene showed functional effects and was associated with the expression of the complex. The homozygous (GG) patients had a better response to radiotherapy with a decreased risk of local recurrence. In carriers of the $\mathrm{C}$ allele, cyclophosphamide-methotrexate-5-fluorouracil (CMF) chemotherapy reduced the risk of distant recurrence. These results suggest that the RAD51 135G > C polymorphism could be a predictive biomarker for effective CMF chemotherapy in early-onset $\mathrm{BC}^{127}$.

Tumor necrosis factor alpha ( $T N F \alpha)$ is a pleiotropic cytokine which can regulate a wide variety of cellular responses; low concentrations of TNF $\alpha$ seem to increase tumor growth and progression ${ }^{128}$. The TNFA-308G > A polymorphism has been found associated with $B C$ survival. Women heterozygous (GA) for this SNP showed a significant disadvantage in progression-free, metastasis-free, and OS compared to homozygous (GG) women ${ }^{129}$. In Mexican patients with $B C$, the frequency of the AA genotype is nearly 14-times higher than in the general population ${ }^{130}$. 


\section{PERSPECTIVES AND CHALLENGES}

As discussed in this review, there is evidence showing that breast tumors in young women are more aggressive and more lethal, and that they present unique biological and molecular features at somatic and germline levels. Breast tissue is subject to continuous changes driven by hormones during the reproductive years and, therefore, pregnancy and breastfeeding may impact not only on $\mathrm{BC}$ risk but also on unique $\mathrm{BC}$ phenotypes and tumor cell biology. However, in most cases, clinical management remains the same regardless of the age at diagnosis. Thus, there is a need to develop a science-driven approach to refine and personalize treatment for YWBC.

miRNAs and epigenetic modifications arise as potentially relevant biomarkers for risk, early diagnosis, and prognosis that can be found in liquid biopsies. The research of novel agents to regulate miRNA expression will also allow targeting miRNAs as therapeutic molecules for the treatment of $\mathrm{BC}^{37}$.

Given that constitutional mutations in genes associated with hereditary $B C$ are more common in YWBC than in postmenopausal patients with BC, international guidelines have recommended that every woman with $B C$ under the age of 40 should be offered genetic counseling before initiating treatment ${ }^{131}$. Although most hereditary $B C$ is attributed to mutations in $B R C A 1$ and $B R C A 2^{132}$, less common hereditary $B C$ mutations should also be considered in young women. Commercially available gene panel tests allow the detection of mutations in a variety of genes associated with BC; these genomic data empower the clinician and the patient for making informed decisions about treatment and follow-up as well as cancer prevention in other family members ${ }^{133}$.

YWBC is a growing burden in Latin America, including Mexico, and research studies indicate that unique molecular biological features of this cancer are associated with age. An optimal characterization of somatic and constitutional genomic signatures offers the potential to identify targetable driver mutations. This effort will improve the treatment and prognosis of YWBC.

\section{ACKNOWLEDGMENTS}

We are grateful to Eduardo Lafuente-Flores from the Instituto de Investigaciones Biomédicas, UNAM, for his help with the design of tables and graphics.

\section{REFERENCES}

1. Ferlay J, Soerjomataram I, Dikshit R, Eser S, Mathers C, Rebelo M, et al. Cancer incidence and mortality worldwide: Sources, methods and major patterns in GLOBOCAN 2012. Int J Cancer. 2015;136:E359-86.

2. Assi HA, Khoury KE, Dbouk H, Khalil LE, Mouhieddine TH, El Saghir NS. Epidemiology and prognosis of breast cancer in young women. J Thorac Dis. 2013;5 Suppl 1:S2-8.

3. Villarreal-Garza C, Aguila C, Magallanes-Hoyos MC, Mohar A, Bargalló $E$, Meneses A, et al. Breast cancer in young women in Latin America: An unmet, growing burden. Oncologist. 2013;18:1298-306.

4. Youlden DR, Cramb SM, Yip CH, Baade PD. Incidence and mortality of female breast cancer in the Asia-Pacific region. Cancer Biol Med. 2014;11:101-15.

5. Chávarri-Guerra Y, Villarreal-Garza C, Liedke PE, Knaul F, Mohar A, Finkelstein DM, et al. Breast cancer in Mexico: A growing challenge to health and the health system. Lancet Oncol. 2012;13:e335-43.

6. Narod SA. Breast cancer in young women. Nat Rev Clin Oncol. 2012;9:460-70.

7. da Santos SS, Melo LR, Koifman RJ, Koifman S. Breast cancer incidence and mortality in women under 50 years of age in Brazil. Cad Saúde Públ. 2013;29:2230-40.

8. Wong IO, Schooling CM, Cowling BJ, Leung GM. Breast cancer incidence and mortality in a transitioning Chinese population: Current and future trends. Br J Cancer. 2015;112:167-70.

9. Han W, Kim SW, Park IA, Kang D, Kim SW, Youn YK, et al. Young age: An independent risk factor for disease-free survival in women with operable breast cancer. BMC Cancer. 2004;4:82.

10. Young Age: The Most Significant Factor Contributing to Poorer Prognosis in Mexican Women with Breast Cancer - Cancerbiology3-1066.pdf. Available from: http://www.jscimedcentral.com/ CancerBiology/cancerbiology-3-1066.pdf. [Last cited on 2017 Mar 08].

11. van der Sangen MJ, Scheepers SW, Poortmans PM, Luiten EJ, Nieuwenhuijzen GA, Voogd AC. Detection of local recurrence following breast-conserving treatment in young women with early breast cancer: Optimization of long-term follow-up strategies. Breast. 2013;22:351-6.

12. van der Sangen MJ, Poortmans PM, Scheepers SW, Lemaire BM, van Berlo CL, Tjan-Heijnen VC, et al. Prognosis following local recurrence after breast conserving treatment in young women with early breast cancer. Eur J Surg Oncol. 2013;39:892-8.

13. Voogd AC, Nielsen M, Peterse JL, Blichert-Toft M, Bartelink H, Overgaard $M$, et al. Differences in risk factors for local and distant recurrence after breast-conserving therapy or mastectomy for Stage I and II breast cancer: Pooled results of two large European randomized trials. J Clin Oncol. 2001;19:1688-97.

14. Lizarraga IM, Sugg SL, Weigel RJ, Scott-Conner CE. Review of risk factors for the development of contralateral breast cancer. Am J Surg. 2013;206:704-8.

15. Davies KR, Cantor SB, Brewster AM. Better contralateral breast cancer risk estimation and alternative options to contralateral prophylactic mastectomy. Int J Womens Health. 2015;7:181-7.

16. Villarreal-Garza C, Mohar A, Bargallo-Rocha JE, Lasa-Gonsebatt F, Reynoso-Noverón N, Matus-Santos J, et al. Molecular subtypes and prognosis in young Mexican women with breast cancer. Clin Breast Cancer. 2016;17:e95-102.

17. Fredholm H, Eaker S, Frisell J, Holmberg L, Fredriksson I, Lindman $\mathrm{H}$. Breast cancer in young women: Poor survival despite intensive treatment. PLoS One. 2009;4:e7695.

18. Collaborative Group on Hormonal Factors in Breast Cancer. Familial breast cancer: Collaborative reanalysis of individual data from 52 epidemiological studies including 58,209 women with breast cancer and 101,986 women without the disease. Lancet. 2001;358:1389-99.

19. Lynch HT, Watson P, Conway T, Fitzsimmons ML, Lynch J. Breast cancer family history as a risk factor for early onset breast cancer. Breast Cancer Res Treat. 1988;11:263-7. 
20. Anders CK, Hsu DS, Broadwater G, Acharya CR, Foekens JA, Zhang $\mathrm{Y}$, et al. Young age at diagnosis correlates with worse prognosis and defines a subset of breast cancers with shared patterns of gene expression. J Clin Oncol. 2008;26:3324-30.

21. Walker RA, Lees E, Webb MB, Dearing SJ. Breast carcinomas occurring in young women ( $<35$ years) are different. $\mathrm{Br}$ J Cancer. 1996;74:1796-800.

22. Kim J, Han W, Jung SY, Park YH, Moon HG, Ahn SK, et al. The value of Ki67 in very young women with hormone receptor-positive breast cancer: Retrospective analysis of 9,321 Korean women. Ann Surg Oncol. 2015;22:3481-8.

23. Morrison DH, Rahardja D, King E, Peng Y, Sarode VR. Tumour biomarker expression relative to age and molecular subtypes of invasive breast cancer. Br J Cancer. 2012;107:382-7.

24. Lee HB, Han W. Unique features of young age breast cancer and its management. J Breast Cancer. 2014;17:301-7.

25. Rosenberg SM, Partridge $\mathrm{AH}$. Management of breast cancer in very young women. Breast. 2015;24 Suppl 2:S154-8.

26. Collins LC, Marotti JD, Gelber S, Cole K, Ruddy K, Kereakoglow S, et al. Pathologic features and molecular phenotype by patient age in a large cohort of young women with breast cancer. Breast Cancer Res Treat. 2012;131:1061-6

27. Copson E, Eccles B, Maishman T, Gerty S, Stanton L, Cutress RI, et al. Prospective observational study of breast cancer treatment outcomes for UK women aged $18-40$ years at diagnosis: The POSH study. J Natl Cancer Inst. 2013;105:978-88.

28. Anders CK, Acharya CR, Hsu DS, Broadwater G, Garman K, Foekens JA, et al. Age-specific differences in oncogenic pathway deregulation seen in human breast tumors. PLoS One. 2008; $3:$ e1373.

29. Azim HA Jr, Nguyen B, Brohée S, Zoppoli G, Sotiriou C. Genomic aberrations in young and elderly breast cancer patients. BMC Med. 2015;13:266

30. Azim HA Jr, Michiels S, Bedard PL, Singhal SK, Criscitiello C, Ignatiadis $\mathrm{M}$, et al. Elucidating prognosis and biology of breast cancer arising in young women using gene expression profiling. Clin Cancer Res. 2012;18:1341-51.

31. Colak D, Nofal A, Albakheet A, Nirmal M, Jeprel H, Eldali A, et al. Age-specific gene expression signatures for breast tumors and cross-species conserved potential cancer progression markers in young women. PLoS One. 2013;8:e63204.

32. Atashgaran V, Wrin J, Barry SC, Dasari P, Ingman WV. Dissecting the biology of menstrual cycle-associated breast cancer risk. Front Oncol. 2016;6:267.

33. Lyons TR, O'Brien J, Borges VF, Conklin MW, Keely PJ, Eliceiri KW, et al. Postpartum mammary gland involution drives progression of ductal carcinoma in situ through collagen and COX-2. Nat Med. 2011;17:1109-15.

34. Azim HA Jr, Brohée S, Peccatori FA, Desmedt C, Loi $S$, Lambrechts $\mathrm{D}$, et al. Biology of breast cancer during pregnancy using genomic profiling. Endocr Relat Cancer. 2014;21:545-54.

35. Hartman EK, Eslick GD. The prognosis of women diagnosed with breast cancer before, during and after pregnancy: A meta-analysis. Breast Cancer Res Treat. 2016;160:347-60.

36. Fornetti J, Martinson HA, Betts CB, Lyons TR, Jindal S, Guo Q, et al. Mammary gland involution as an immunotherapeutic target for postpartum breast cancer. J Mammary Gland Biol Neoplasia. 2014;19:213-28.

37. Kurozumi S, Yamaguchi $Y$, Kurosumi M, Ohira M, Matsumoto $H$, Horiguchi J. Recent trends in microRNA research into breast cancer with particular focus on the associations between microRNAs and intrinsic subtypes. J Hum Genet. 2017; 62:15-24

38. Bertoli G, Cava C, Castiglioni I. MicroRNAs: New biomarkers for diagnosis, prognosis, therapy prediction and therapeutic tools for breast cancer. Theranostics. 2015;5:1122-43.

39. Rupaimoole R, Slack FJ. MicroRNA therapeutics: Towards a new era for the management of cancer and other diseases. Nat Rev Drug Discov. 2017;16:203-22.

40. Peña-Chilet M, Martínez MT, Pérez-Fidalgo JA, Peiró-Chova L, Oltra SS, Tormo E, et al. MicroRNA profile in very young women with breast cancer. BMC Cancer. 2014;14:529.
41. Li Y, Xu Y, Yu C, Zuo W. Associations of miR-146a and miR-146b expression and breast cancer in very young women. Cancer Biomark. 2015;15:881-7.

42. Nassar FJ, El Sabban M, Zgheib NK, Tfayli A, Boulos F, Jabbour M, et al. miRNA as potential biomarkers of breast cancer in the Lebanese population and in young women: A pilot study. PLoS One. 2014;9:e107566.

43. Garcia AI, Buisson M, Bertrand P, Rimokh R, Rouleau E, Lopez BS, et al. Down-regulation of BRCA1 expression by miR-146a and miR-146b-5p in triple negative sporadic breast cancers. EMBO Mol Med. 2011;3:279-90.

44. Han M, Liu M, Wang Y, Chen X, Xu J, Sun Y, et al. Antagonism of miR-21 reverses epithelial-mesenchymal transition and cancer stem cell phenotype through AKT/ERK $1 / 2$ inactivation by targeting PTEN. PLoS One. 2012;7:e39520.

45. Buscaglia LE, Li Y. Apoptosis and the target genes of microRNA-21. Chin J Cancer. 2011;30:371-80.

46. Cimino D, De Pittà C, Orso F, Zampini M, Casara S, Penna E, et al. miR148b is a major coordinator of breast cancer progression in a relapse-associated microRNA signature by targeting ITGA5, ROCK1, PIK3CA, NRAS, and CSF1. FASEB J. 2013;27:1223-35.

47. Ma L, Teruya-Feldstein J, Weinberg RA. Tumour invasion and metastasis initiated by microRNA-10b in breast cancer. Nature. 2007:449:682-8

48. Bahrami A, Aledavood A, Anvari K, Hassanian SM, Maftouh M, Yaghobzade A, et al. The prognostic and therapeutic application of microRNAs in breast cancer: Tissue and circulating microRNAs. J Cell Physiol. 2017.

49. Nassar FJ, Nasr R, Talhouk R. MicroRNAs as biomarkers for early breast cancer diagnosis, prognosis and therapy prediction. Pharmacol Ther. 2016;172:34-49

50. Tang Q, Cheng J, Cao X, Surowy H, Burwinkel B. Blood-based DNA methylation as biomarker for breast cancer: A systematic review. Clin Epigenetics. 2016;8:115.

51. Cai Y, Tsai HC, Yen RC, Zhang YW, Kong X, Wang W, et al. Critical threshold levels of DNA methyltransferase 1 are required to maintain DNA methylation across the genome in human cancer cells. Genome Res. 2017;27:533-44.

52. Wong EM, Southey MC, Fox SB, Brown MA, Dowty JG, Jenkins $M A$, et al. Constitutional methylation of the BRCA1 promoter is specifically associated with BRCA1 mutation-associated pathology in early-onset breast cancer. Cancer Prev Res (Phila). 2011;4:23-33.

53. Scott CM, Joo JE, O'Callaghan N, Buchanan DD, Clendenning $M$, Giles GG, et al. Methylation of breast cancer predisposition genes in early-onset breast cancer: Australian breast cancer family registry. PLoS One. 2016:11:e0165436.

54. Forbes SA, Beare D, Boutselakis H, Bamford S, Bindal N, Tate J, et al. COSMIC: Somatic cancer genetics at high-resolution. Nucleic Acids Res. 2017;45:D777-D783.

55. Forbes SA, Beare D, Bindal N, Bamford S, Ward S, Cole CG, et al. COSMIC: High-resolution cancer genetics using the catalogue of somatic mutations in cancer. Curr Protoc Hum Genet. 2016; 91:10.11.1-10.11.37.

56. Encinas G, Maistro S, Pasini FS, Katayama ML, Brentani MM, Bock $\mathrm{GH}$, et al. Somatic mutations in breast and serous ovarian cancer young patients: A systematic review and meta-analysis. Rev Assoc Med Bras. 2015:61:474-83.

57. Cohen H, Ben-Hamo R, Gidoni M, Yitzhaki I, Kozol R, Zilberberg A, et al. Shift in GATA3 functions, and GATA3 mutations, control progression and clinical presentation in breast cancer. Breast Cancer Res. 2014;16:464.

58. Gaynor KU, Grigorieva IV, Allen MD, Esapa CT, Head RA, Gopinath $\mathrm{P}$, et al. GATA3 mutations found in breast cancers may be associated with aberrant nuclear localization, reduced transactivation and cell invasiveness. Horm Cancer. 2013;4:123-39.

59. Adomas AB, Grimm SA, Malone C, Takaku M, Sims JK, Wade PA. Breast tumor specific mutation in GATA3 affects physiological mechanisms regulating transcription factor turnover. BMC Cancer. 2014;14:278.

60. Chou J, Provot S, Werb Z. GATA3 in development and cancer differentiation: Cells GATA have it!. J Cell Physiol. 2010;222:42-9. 
61. Economopoulou P, Dimitriadis G, Psyrri A. Beyond BRCA: New hereditary breast cancer susceptibility genes. Cancer Treat Rev. 2015;41:1-8.

62. Rich TA, Woodson AH, Litton J, Arun B. Hereditary breast cancer syndromes and genetic testing. J Surg Oncol. 2015;111: 66-80.

63. Apostolou P, Fostira F. Hereditary breast cancer: The era of new susceptibility genes. Biomed Res Int. 2013;2013:747318.

64. Antoniou A, Pharoah PD, Narod S, Risch HA, Eyfjord JE, Hopper JL, et al. Average risks of breast and ovarian cancer associated with BRCA1 or BRCA2 mutations detected in case series unselected for family history: A combined analysis of 22 studies. Am J Hum Genet. 2003;72:1117-30.

65. Malone KE, Daling JR, Neal C, Suter NM, O'Brien C, CushingHaugen $K$, et al. Frequency of BRCA1/BRCA2 mutations in a population-based sample of young breast carcinoma cases. Cancer. 2000;88:1393-402

66. Villarreal-Garza C, Weitzel JN, Llacuachaqui M, Sifuentes E, Magallanes-Hoyos MC, Gallardo L, et al. The prevalence of BRCA1 and BRCA2 mutations among young Mexican women with triple-negative breast cancer. Breast Cancer Res Treat. 2015;150:389-94

67. Sorrell AD, Espenschied CR, Culver JO, Weitzel JN. Tumor protein p53 (TP53) testing and Li-Fraumeni syndrome: current status of clinical applications and future directions. Mol Diagn Ther. 2013;17:31-47.

68. Torres-Mejía G, Royer R, Llacuachaqui M, Akbari MR, Giuliano AR, Martínez-Matsushita L, et al. Recurrent BRCA1 and BRCA2 mutations in Mexican women with breast cancer. Cancer Epidemiol Biomark Prev. 2015;24:498-505.

69. Masciari S, Dillon DA, Rath M, Robson M, Weitzel JN, Balmana J, et al. Breast cancer phenotype in women with TP53 germline mutations: A Li-Fraumeni syndrome consortium effort. Breast Cancer Res Treat. 2012;133:1125-30.

70. Soussi T, Wiman KG. TP53: An oncogene in disguise. Cell Death Differ. 2015;22:1239-49.

71. Gonzalez KD, Noltner KA, Buzin CH, Gu D, Wen-Fong $C Y$, Nguyen VQ, et al. Beyond Li Fraumeni syndrome: Clinical characteristics of families with p53 germline mutations. J Clin Oncol. 2009;27:1250-6

72. Damineni S, Rao VR, Kumar S, Ravuri RR, Kagitha S, Dunna NR et al. Germline mutations of TP53 gene in breast cancer. Tumour Biol. 2014:35:9219-27.

73. Mouchawar J, Korch C, Byers T, Pitts TM, Li E, McCredie MR, et al. Population-based estimate of the contribution of TP53 mutations to subgroups of early-onset breast cancer: Australian Breast Cancer Family Study. Cancer Res. 2010;70:4795-800.

74. Hobert JA, Eng C. PTEN hamartoma tumor syndrome: An overview. Genet Med. 2009;11:687-94.

75. Ngeow J, Sesock K, Eng C. Breast cancer risk and clinical implications for germline PTEN mutation carriers. Breast Cancer Res Treat. 2015.

76. Tan MH, Mester JL, Ngeow J, Rybicki LA, Orloff MS, Eng C. Lifetime cancer risks in individuals with germline PTEN mutations. Clin Cancer Res Off J Am Assoc Cancer Res. 2012;18:400-7.

77. Pradella LM, Evangelisti C, Ligorio C, Ceccarelli C, Neri I, Zuntini R et al. A novel deleterious PTEN mutation in a patient with early-onset bilateral breast cancer. BMC Cancer. 2014;14:70

78. Ataei-Kachouei M, Nadaf J, Akbari MT, Atri M, Majewski J, Riazalhosseini $Y$, et al. Double heterozygosity of BRCA2 and STK11 in familial breast cancer detected by exome sequencing. Iran J Public Health. 2015;44:1348-52.

79. Turpin A, Cattan S, Leclerc J, Wacrenier A, Manouvrier-Hanu S, Buisine MP, et al. Hereditary predisposition to cancers of the digestive tract, breast, gynecological and gonadal: Focus on the Peutz-Jeghers. Bull Cancer. 2014;101:813-22

80. van Lier MG, Wagner A, Mathus-Vliegen EM, Kuipers EJ, Steyerberg EW, van Leerdam ME. High cancer risk in PeutzJeghers syndrome: A systematic review and surveillance recommendations. Am J Gastroenterol. 2010;105:1258-64.

81. Resta N, Pierannunzio D, Lenato GM, Stella A, Capocaccia R Bagnulo R, et al. Cancer risk associated with STK11/LKB1 germline mutations in Peutz-Jeghers syndrome patients: Results of an Italian multicenter study. Dig Liver Dis. 2013;45:606-11.

82. Lorenzo Liñán MÁ, Lorenzo Campos M, Motos Micó J, Martínez Pérez C, Gumbau Puchol V. Bilateral breast cancer and PeutzJeghers syndrome. Cir Esp. 2013;91:195-7.

83. Hearle N, Schumacher V, Menko FH, Olschwang S, Boardman LA, Gille JJ, et al. Frequency and spectrum of cancers in the PeutzJeghers syndrome. Clin Cancer Res. 2006;12:3209-15.

84. $\mathrm{CDH} 1$ Cadherin 1 [Homo Sapiens (Human)]-Gene-NCBI. Available from: http://www.ncbi.nlm.nih.gov/gene/999. [Last cited on 2017 Mar 30].

85. Kluijt I, Sijmons RH, Hoogerbrugge N, Plukker JT, de Jong D, van Krieken JH, et al. Familial gastric cancer: Guidelines for diagnosis, treatment and periodic surveillance. Fam Cancer. 2012;11: 363-9.

86. Petridis C, Shinomiya I, Kohut K, Gorman P, Caneppele M Shah V, et al. Germline $\mathrm{CDH} 1$ mutations in bilateral lobular carcinoma in situ. Br J Cancer. 2014;110:1053-7.

87. Masciari S, Larsson N, Senz J, Boyd N, Kaurah P, Kandel MJ, et al. Germline E-cadherin mutations in familial lobular breast cancer. J Med Genet. 2007;44:726-31.

88. Xie ZM, Li LS, Laquet C, Penault-Llorca F, Uhrhammer N, Xie XM, et al. Germline mutations of the E-cadherin gene in families with inherited invasive lobular breast carcinoma but no diffuse gastric cancer. Cancer. 2011;117:3112-7.

89. Schrader KA, Masciari S, Boyd N, Salamanca C, Senz J, Saunders DN, et al. Germline mutations in $\mathrm{CDH} 1$ are infrequent in women with early-onset or familial lobular breast cancers. J Med Genet. 2011;48:64-8.

90. CHEK Breast Cancer Case-Control Consortium. CHEK $2 * 1100$ delC and susceptibility to breast cancer: A collaborative analysis involving 10,860 breast cancer cases and 9,065 controls from 10 studies. Am J Hum Genet. 2004;74:1175-82.

91. Weischer M, Bojesen SE, Ellervik C, Tybjaerg-Hansen A Nordestgaard BG. CHEK2*1100delC genotyping for clinical assessment of breast cancer risk: Meta-analyses of 26,000 patient cases and 27,000 controls. J Clin Oncol. 2008;26:542-8.

92. Rashid MU, Muhammad N, Faisal S, Amin A, Hamann U. Constitutional CHEK2 mutations are infrequent in early-onset and familial breast/ovarian cancer patients from Pakistan. BMC Cancer. 2013:13:312.

93. Baloch AH, Daud S, Raheem N, Luqman M, Ahmad A, Rehman A, et al. Missense mutations (p.H371Y, p.D438Y) in gene CHEK2 are associated with breast cancer risk in women of Balochistan origin. Mol Biol Rep. 2014;41:1103-7.

94. Wang N, Ding H, Liu C, Li X, Wei L, Yu J, et al. A novel recurrent CHEK2 Y390C mutation identified in high-risk Chinese breast cancer patients impairs its activity and is associated with increased breast cancer risk. Oncogene. 2015;34:5198-205.

95. Antoniou AC, Casadei S, Heikkinen T, Barrowdale D, Pylkäs K, Roberts J, et al. Breast-cancer risk in families with mutations in PALB2. N Engl J Med. 2014;371:497-506.

96. Ding YC, Steele L, Chu LH, Kelley K, Davis H, John EM, et al. Germline mutations in PALB2 in African-American breast cancer cases. Breast Cancer Res Treat. 2011;126:227-30.

97. Erkko H, Xia B, Nikkilä J, Schleutker J, Syrjäkoski K, Mannermaa A et al. A recurrent mutation in PALB2 in Finnish cancer families. Nature. 2007:446:316-9.

98. Foulkes WD, Ghadirian P, Akbari MR, Hamel N, Giroux S, Sabbaghian $\mathrm{N}$, et al. Identification of a novel truncating PALB2 mutation and analysis of its contribution to early-onset breast cancer in French-Canadian women. Breast Cancer Res. 2007;9:R83.

99. García MJ, Fernández V, Osorio A, Barroso A, Llort G, Lázaro C, et al. Analysis of FANCB and FANCN/PALB2 fanconi anemia genes in BRCA1/2-negative Spanish breast cancer families. Breast Cancer Res Treat. 2009;113:545-51

100. Sluiter M, Mew S, van Rensburg EJ. PALB2 sequence variants in young South African breast cancer patients. Fam Cancer. 2009; 8:347-53.

101. Thompson D, Duedal S, Kirner J, McGuffog L, Last J, Reiman A, et al. Cancer risks and mortality in heterozygous ATM mutation carriers. J Natl Cancer Inst. 2005;97:813-22. 
102. Morrell D, Cromartie E, Swift M. Mortality and cancer incidence in 263 patients with ataxia-telangiectasia. J Natl Cancer Inst. 1986;77:89-92.

103. Lin PH, Kuo WH, Huang AC, Lu YS, Lin CH, Kuo SH, et al. Multiple gene sequencing for risk assessment in patients with early-onset or familial breast cancer. Oncotarget. 2016;7:8310-20.

104. Izatt L, Greenman J, Hodgson S, Ellis D, Watts S, Scott G, et al. Identification of germline missense mutations and rare allelic variants in the ATM gene in early-onset breast cancer. Genes Chromosomes Cancer. 1999;26:286-94.

105. Teraoka SN, Malone KE, Doody DR, Suter NM, Ostrander EA, Daling JR, et al. Increased frequency of ATM mutations in breast carcinoma patients with early onset disease and positive family history. Cancer. 2001;92:479-87.

106. Byrnes GB, Southey MC, Hopper JL. Are the so-called low penetrance breast cancer genes, ATM, BRIP1, PALB2 and CHEK2, high risk for women with strong family histories? Breast Cancer Res. 2008;10:208

107. Churpek JE, Walsh T, Zheng Y, Moton Z, Thornton AM, Lee MK, et al. Inherited predisposition to breast cancer among African American women. Breast Cancer Res Treat. 2015;149:31-9.

108. Couch FJ, Hart SN, Sharma P, Toland AE, Wang X, Miron P, et al. Inherited mutations in 17 breast cancer susceptibility genes among a large triple-negative breast cancer cohort unselected for family history of breast cancer. J Clin Oncol. 2015;33:304-11.

109. Karppinen SM, Heikkinen K, Rapakko K, Winqvist R. Mutation screening of the BARD1 gene: Evidence for involvement of the Cys557Ser allele in hereditary susceptibility to breast cancer. J Med Genet. 2004;41:e114.

110. Stacey SN, Sulem P, Johannsson OT, Helgason A, Gudmundsson J, Kostic JP, et al. The BARD1 Cys557Ser variant and breast cancer risk in Iceland. PLoS Med. 2006;3:e217.

111. Williams RS, Williams JS, Tainer JA. Mre11-Rad50-Nbs1 is a keystone complex connecting DNA repair machinery, double-strand break signaling, and the chromatin template. Biochem Cell Biol. 2007;85:509-20.

112. Damiola F, Pertesi M, Oliver J, Le Calvez-Kelm F, Voegele C, Young EL, et al. Rare key functional domain missense substitutions in MRE11A, RAD50, and NBN contribute to breast cancer susceptibility: Results from a Breast Cancer Family Registry case-control mutation-screening study. Breast Cancer Res. 2014;16:R58

113. Zhang ZH, Yang LS, Huang F, Hao JH, Su PY, Sun YH. Current evidence on the relationship between two polymorphisms in the NBS1 gene and breast cancer risk: A meta-analysis. Asian Pac J Cancer Prev. 2012;13:5375-9.

114. Zhang G, Zeng Y, Liu Z, Wei W. Significant association between Nijmegen breakage syndrome 1657 del5 polymorphism and breast cancer risk. Tumour Biol. 2013;34:2753-7.

115. Dembowska-Baginska B, Perek D, Brozyna A, Wakulinska A, Olczak-Kowalczyk D, Gladkowska-Dura M, et al. Non-hodgkin lymphoma (NHL) in children with Nijmegen breakage syndrome (NBS). Pediatr Blood Cancer. 2009;52:186-90.

116. Suwaki N, Klare K, Tarsounas M. RAD51 paralogs: Roles in DNA damage signalling, recombinational repair and tumorigenesis. Semin Cell Dev Biol. 2011;22:898-905

117. Unger-Saldaña K, Miranda A, Zarco-Espinosa G, MaineroRatchelous F, Bargalló-Rocha E, Miguel Lázaro-León J. Health system delay and its effect on clinical stage of breast cancer: Multicenter study. Cancer. 2015;121:2198-206.

118. Scully R, Chen J, Plug A, Xiao Y, Weaver D, Feunteun J, et al. Association of BRCA1 with Rad51 in mitotic and meiotic cells. Cell. 1997;88:265-75.
119. Wong AK, Pero R, Ormonde PA, Tavtigian SV, Bartel PL. RAD51 interacts with the evolutionarily conserved BRC motifs in the human breast cancer susceptibility gene brca2. J Biol Chem. 1997;272:31941-4

120. Dray E, Etchin J, Wiese C, Saro D, Williams GJ, Hammel M, et al. Enhancement of RAD51 recombinase activity by the tumor suppressor PALB2. Nat Struct Mol Biol. 2010;17:1255-9.

121. Golmard L, Caux-Moncoutier V, Davy G, Al Ageeli E, Poirot B, Tirapo C, et al. Germline mutation in the RAD51B gene confers predisposition to breast cancer. BMC Cancer. 2013;13:484.

122. Michailidou K, Beesley J, Lindstrom S, Canisius S, Dennis J, Lush MJ, et al. Genome-wide association analysis of more than 120,000 individuals identifies 15 new susceptibility loci for breast cancer. Nat Genet. 2015;47:373-80.

123. Ahsan H, Halpern J, Kibriya MG, Pierce BL, Tong L, Gamazon E, et al. A genome-wide association study of early-onset breast cancer identifies PFKM as a novel breast cancer gene and supports a common genetic spectrum for breast cancer at any age. Cancer Epidemiol Biomark Prev. 2014;23:658-69.

124. Barnholtz-Sloan JS, Shetty PB, Guan X, Nyante SJ, Luo J, Brennan DJ, et al. FGFR2 and other loci identified in genomewide association studies are associated with breast cancer in African-American and younger women. Carcinogenesis. 2010; 31:1417-23

125. Fejerman L, Stern MC, John EM, Torres-Mejía G, Hines LM, Wolff RK, et al. Interaction between common breast cancer susceptibility variants, genetic ancestry, and nongenetic risk factors in hispanic women. Cancer Epidemiol Biomark Prev. 2015;24:1731-8.

126. Söderlund K, Skoog L, Fornander T, Askmalm MS. The BRCA1/ BRCA2/Rad51 complex is a prognostic and predictive factor in early breast cancer. Radiother Oncol. 2007;84:242-51.

127. Söderlund Leifler K, Asklid A, Fornander T, Stenmark Askmalm M. The RAD51 135G>C polymorphism is related to the effect of adjuvant therapy in early breast cancer. J Cancer Res Clin Oncol. 2015;141:797-804

128. Liu D, Wang X, Chen Z. Tumor necrosis factor-a, a regulator and therapeutic agent on breast cancer. Curr Pharm Biotechnol. 2016;17:486-94.

129. Korobeinikova E, Myrzaliyeva D, Ugenskiene R, Raulinaityte D, Gedminaite J, Smigelskas K, et al. The prognostic value of IL10 and TNF alpha functional polymorphisms in premenopausal early-stage breast cancer patients. BMC Genet. 2015;16:70.

130. Gómez Flores-Ramos L, Escoto-De Dios A, Puebla-Pérez AM, Figuera-Villanueva LE, Ramos-Silva A, Ramírez-Patiño $R$, et al. Association of the tumor necrosis factor-alpha-308G $>$ A polymorphism with breast cancer in Mexican women. Genet Mol Res. 2013;12:5680-93.

131. Paluch-Shimon S, Pagani O, Partridge AH, Bar-Meir E, Fallowfield L, Fenlon $D$, et al. Second international consensus guidelines for breast cancer in young women (BCY2). Breast. 2016;26:87-99.

132. Nelson HD, Fu R, Goddard K, Mitchell JP, Okinaka-Hu L, Pappas M, et al. Risk Assessment, Genetic Counseling, and Genetic Testing for BRCA-Related Cancer: Systematic Review to Update the U. S. Preventive Services Task Force Recommendation. Rockville, MD: Agency for Healthcare Research and Quality (US); 2013. Available from: http://www.ncbi.nlm.nih.gov/ books/NBK179201. [Last cited on 2017 Mar 10].

133. Kaphingst KA, Ivanovich J, Elrick A, Dresser R, Matsen C, Goodman MS. How, who, and when: Preferences for delivery of genome sequencing results among women diagnosed with breast cancer at a young age. Mol Genet Genomic Med. 2016; 4:684-95 